Revista de la red interuniversitaria de estudios sobre las literaturas rioplatenses contemporáneas en Francia

$11 \mid 2014$

De niños e infancias

\title{
Atlas de costumbres salvajes de Norteamérica
}

\section{Diego Vecchio}

\section{OpenEdition}

\section{Journals}

Edición electrónica

URL: http://journals.openedition.org/lirico/1833

DOI: $10.4000 /$ lirico. 1833

ISSN: 2262-8339

Editor

Réseau interuniversitaire d'étude des littératures contemporaines du Río de la Plata

\section{Referencia electrónica}

Diego Vecchio, «Atlas de costumbres salvajes de Norteamérica », Cuadernos LIRICO [En línea],

11 | 2014, Puesto en línea el 01 diciembre 2014, consultado el 04 mayo 2019. URL : http:// journals.openedition.org/lirico/1833; DOI : 10.4000/lirico.1833

Este documento fue generado automáticamente el 4 mayo 2019.

\section{cc) () $\Theta$}

Cuadernos LIRICO está distribuido bajo una Licencia Creative Commons Atribución-NoComercialSinDerivar 4.0 Internacional. 


\title{
Atlas de costumbres salvajes de Norteamérica
}

\author{
Diego Vecchio
}

\section{NOTA DEL EDITOR}

Diego Vecchio (Buenos Aires, 1969). Narrador, ensayista y traductor, desde 1992 reside en París. Publicó Historia calamitatum (Buenos Aires, Paradiso, 2000), Egocidio : Macedonio Fernández y la liquidación del yo (Rosario, Beatriz Viterbo, 2003), Microbios (Rosario, Beatriz Viterbo, 2006) y Osos (Rosario, Beatriz Viterbo, 2010). Sus ficciones han sido traducidas al francés y al portugués.

1 Cerca de la localidad de Hat Mountain, situada en los territorios de Oregon, fue descubierto uno de los pueblos más atrasados, por no decir el más atrasado de la humanidad. Aislado de los otros pueblos y tribus por desfiladeros infranqueables, ha conservado en un estado de pureza excepcional costumbres que desaparecieron de la faz de la tierra desde hace miles de años. Los naturales de Hat Mountain son verdaderos fósiles vivientes de la infancia del hombre.

2 No conocen la propiedad privada ni la familia. No construyen casas ni chozas. No practican ni la pesca ni la caza ni la agricultura ni la domesticación de animales. Desconocen la religión, aún en sus formas más rudimentarias, como así también la alfarería o el arte. No saben fabricar arcos ni flechas, ni encender fuego o cocer alimentos. Como en la prehistoria, los naturales de Hat Mountain viven en pandillas, gobernadas por un patriarca tiránico que goza de todas las hembras y expulsa a los machos más jóvenes, una vez alcanzada la edad de madurez sexual, a fin de evitar toda rivalidad o pendencia.

4 La tiranía del patriarca suele declinar por sí sola. Aquel monstruo implacable que goza de todas las mujeres, se convierte, con el paso del tiempo, en un viejo enclenque, harto gastado por los excesos cometidos durante su juventud, que apenas sí puede dar un paseo matinal, con sus piernas flacas y torcidas, apoyándose en un palo. Los naturales de Hat Mountain desconocen lo que es un cayado o bastón, que corresponde a un estado más 
avanzado de la civilización, ni mucho menos las muletas o la silla de ruedas, invenciones que solo se encuentran entre los pueblos en la vanguardia del progreso.

El caso es que las damas de Hat Mountain acuden incesantemente a solicitar sus favores, en recuerdo de las hazañas de antaño, tan celebradas por mito, sagas y chismes. El venerable anciano les ruega encarecidamente que lo dejen tranquilo. Pero las damas vuelven a acometerlo con sus proposiciones, caricias y toqueteos. El pobre hombre las rechaza, amenazándolas con un puño cerrado, no sin vehemencia, esfuerzo que lo deja extenuado, durante horas.

6 Con la esperanza de atizar la lumbre del deseo, las más jóvenes le sirven raíces afrodisíacas, que el geronte se pone a chupar, con sus encías desdentadas. Lamentablemente, una vez terminado el banquete, el viejo se echa a dormir. En medio de la noche, cuando se despierta sobresaltado por algún sueño, consagra una chispa de su energía libidinal, no a la fornicación que podría hacerle estallar alguna arteria, sino al reprensible vicio que perdió a Onán.

7 No es de sorprender que, emancipándose de ese avasallamiento decrépito, muchas de las consortes hayan resuelto entregarse a las delicias sáficas, descubriendo un continente que nunca más abandonarán. Otras, escrupulosamente respetuosas de la tradición, han preferido restablecer contacto con los machos más jóvenes expulsados. ¡Demasiado tarde! Mientras el patriarca envejecía, heridos en su orgullo por el comportamiento de las hembras que no habían manifestado el menor gesto de solidaridad, estos jóvenes se han abandonado a todo tipo de acrobacia sexual entre varones y estas costumbres contranaturales, por el momento, parecen irreversibles. 